\title{
Anti-fossil fuel norms
}

\author{
Fergus Green ${ }^{1}$
}

Received: 18 April 2017 / Accepted: 23 December 2017 / Published online: 1 February 2018

(C) The Author(s) 2018. This article is an open access publication

\begin{abstract}
Historically, climate governance initiatives and associated scholarship have all but ignored the potential for "global moral norms" to bring about changes in the political conditions for global climate mitigation. This is surprising, since global moral norms are widely employed - as both a mode of governance and an analytical framework - in other domains of global governance, from international security to human rights. However, recent national-level fossil fuel divestments, moratoria on new coal mines and bans on gas fracking, among other developments, suggest the promise of global moral norms prohibiting fossil fuel-related activities, which this article terms "anti-fossil fuel norms" (AFFNs). The article interprets recent examples of such activities in the light of international relations theory on moral norms to provide a general framework for understanding how AFFNs originate, spread and affect states. Specifically, the article argues that there are: (i) influential agents that are originating, and likely to continue to originate, AFFNs; and (ii) international and domestic mechanisms by which AFFNs are likely to spread widely among states and have a significant causal effect on the identity-related considerations or rational calculations of states in the direction of limiting or reducing the production or consumption of fossil fuels. The article also shows that, because they spread and affect state behaviour through mechanisms of "international socialization" and domestic "political mobilization", AFFNs cohere with and build upon the new paradigm of global climate governance crystallized in the Paris Agreement. AFFNs, the article concludes, represent a promising new frontier in climate governance.
\end{abstract}

\section{Introduction}

Testing nuclear weapons, owning slaves and waging aggressive war were all once normal practices - in some cases, for much of human history. Today, robust global moral norms

This article is part of a Special Issue on "Fossil Fuel Supply and Climate Policy" edited by Harro van Asselt and Michael Lazarus.

Electronic supplementary material The online version of this article (https://doi.org/10.1007/s10584-0172134-6) contains supplementary material, which is available to authorized users.

Fergus Green

R.F.Green@1se.ac.uk

1 London School of Economics and Political Science, London, UK 
socially condition states and their citizens to see these practices as morally wrong, and to regulate them accordingly. What prospect is there for the exploitation of fossil fuels to meet the same fate?

Not long ago, the prospect might have seemed fantastical. But recent national-level fossil fuel divestments, ${ }^{1}$ commitments to phase out coal-fired power stations, ${ }^{2}$ moratoria on new coalmines $^{3}$ and bans on gas fracking ${ }^{4}$ suggest otherwise. These and other recent political and policy developments concerning fossil fuels can usefully be interpreted - in the light of international relations theory on global moral norms - as practices that instantiate what I call "anti-fossil fuel norms" (AFFNs). AFFNs, I argue, constitute a promising new frontier in climate governance (construed broadly as authoritative social steering toward a collective climate change goal: cf. Andonova et al. 2009; Gunningham 2017a, 316).

A norm is a standard of appropriate behaviour that is expected of an agent with a particular identity (Finnemore and Sikkink 1998, 891). A global moral norm is a norm that (i) pertains to states and globally significant non-state actors (such as international organizations and multinational corporations) and (ii) originates from concerted attempts to change what counts as appropriate behaviour for those agents in line with a conception of justice or ethics. Especially relevant to the present article are global moral norms whose moral-normative content consists in the direct prohibition of some action, process or product-for example, the construction of new coalmines. These features distinguish the kind of norms with which I am concerned from various related ideational phenomena. First, their moral content distinguishes them from social norms whose content is merely conventional/customary. Second, their global scope, and their focus on states and globally significant non-state actors, distinguishes them from norms with merely local scope and/or applicable to other kinds of actors. Third, their deontic content distinguishes them from merely conceptual phenomena in the international climate regime (e.g. "sustainable development"). Fourth, their specific focus on direct prohibition distinguishes them from the more abstract, less determinate normative theories and principles that have been extensively analyzed by philosophers, international lawyers and climate policy scholars (e.g. "climate justice", "common but differentiated responsbilities"). ${ }^{5}$

The potential role of global moral norms (of the kind with which I am concerned) as a mode of climate governance has been almost entirely neglected by scholars. ${ }^{6}$ For example, it is not covered in either the "International Cooperation" chapter of the IPCC's Working Group III report (Stavins et al. 2014) or the 600-page Research Handbook on Climate Governance (Bäckstrand and Lövbrand 2015). This neglect is probably partly explained by the way the international climate regime has evolved (see Online Resource 1). Nonetheless, the neglect is striking.

Following the literature on how global moral norms originate, spread and effect change, I argue that there are (i) influential agents that are originating, and likely to continue to originate, AFFNs (Section 2); and (ii) domestic and international processes by which AFFNs are likely

\footnotetext{
${ }^{1}$ See, e.g., Osborne (2017).

${ }^{2}$ See the Powering Past Coal Alliance (Government of Canada 2017), discussed in Section 3.2.1, below.

${ }^{3}$ See Blondeel and Van de Graaf (2018).

${ }^{4}$ See https://keeptapwatersafe.org/global-bans-on-fracking/.

5 That said, AFFNs are related in various ways to some of these other kinds of ideational phenomena (see Online Resource 1).

${ }^{6}$ Exceptions include a number of contributions to a special issue of Law \& Policy on fossil fuel divestment, published in October 2017 (see especially Gunningham 2017a, 2017b). Before that, the potential value of developing new climate-related global moral norms was discussed in Raymond et al. (2014) and mentioned briefly by Caney (2014, 137-38) and Drahos and Downie (2016, 7). See also Blondeel and Van de Graaf (2018).
} 
to spread widely among states and have a significant causal effect on the identity-related considerations or rational calculations of states in the direction of limiting or reducing the production or consumption of fossil fuels (Section 3). These processes are, respectively, domestic "political mobilization" (Section 3.1) and "international socialization" (Section 3.2).

Political mobilization and international socialization processes are, it so happens, central to the "new global climate governance approach" crystallized in the Paris Agreement (Falkner 2016, 1108), which marks a critical departure from previous international attempts to govern the climate using hierarchical mechanisms involving enforceable incentives, including regulatedmarket mechanisms, as exemplified by the Kyoto Protocol. Because of this change in the international climate policy paradigm, along with innovation in energy systems and shifts in the interests of powerful states, global structural conditions are more conducive to the spread of AFFNs than they were even at the beginning of this decade, let alone in the 1990s or 2000s. This structural context is discussed further in the online supplement (Online Resource 1), which provides useful background to the main claims advanced in this article.

Methodologically, this article's contribution is theoretical. Its main claims add up to a general model or framework for explaining how AFFNs originate, spread and affect statesand how they are likely to do so in future. Accordingly, my claims are primarily supported by reference to established theory; providing detailed empirical support is beyond the scope of the article. However, illustrative evidence from recent political behaviour concerning fossil fuels, discussed throughout the paper, enhances the plausibility of these claims, which can be used as testable hypotheses in future systematic empirical work. Given the historical neglect of moral norms in climate governance research, it is hoped that this contribution will open up a valuable new frontier in research on both climate governance and international norms, and also help AFFN proponents to reflect critically on their practices.

\section{The emergence of AFFNs: norm entrepreneurs and norm champions}

Global moral norms are often originated by norm entrepreneurs - typically individuals who are highly motivated to overcome a perceived injustice/problem and who work through an organizational platform (such as an NGO, a social movement, or an international organization) to get a new standard of behaviour normalized in the international system (Finnemore and Sikkink 1998, 895-901). ${ }^{7}$ The existing (unjust/problematic) practice that norm entrepreneurs seek to change will, by definition, be "normal" and subject to its own "logics of appropriateness" (March and Olsen 1996), around which various interests have coalesced. Accordingly, norm entrepreneurs must challenge those existing logics and interests using creative tactics (Finnemore and Sikkink 1998, 897).

Norm entrepreneurs can be distinguished from "norm champions"-enthusiastic early adopters of a norm who pressure others to adopt the norm (Fitzsimmons 2009). ${ }^{8}$ Norm champions can be state or non-state actors and can operate via domestic or international channels (cf. Finnemore and Sikkink 1998, 902; Fitzsimmons 2009, 12). Norm entrepreneurs and champions often become linked through "transnational advocacy networks" that agitate for normative change at multiple levels (Keck and Sikkink 1998).

\footnotetext{
${ }^{7}$ Norm entrepreneurs could also be public officials working through a state, though this is atypical.

${ }^{8}$ Finnemore and Sikkink $(1998,902)$ call them "agents of socialization". The distinction between norm entrepreneurs and norm champions is not especially important in practice-both are "agents of socialization".
} 
AFFNs have to date originated from or been advocated by at least four kinds of norm entrepreneurs or champions. They have mostly originated from individuals and organizations within civil society in the years following the failed Copenhagen climate conference (see Online Resource 1). An example is the prominent environmental activist, Bill McKibben (see Schifeling and Hoffman 2017). Motivated by a conviction that building a social movement by mobilizing moral outrage against fossil fuel companies is likely to be more politically effective than previous climate efforts (McKibben 2012), McKibben sparked the social movement campaigning for fossil fuel divestment and has championed protest action against new fossil fuel infrastructure. Anti-fossil fuel initiatives are increasingly being endorsed by other, more mainstream elites and organizations within civil society. ${ }^{9}$ Pope Francis, for example, endorsed phasing out fossil fuels in his encyclical, Laudato Si' (2015, para. 165).

International organizations and their senior executive officers are also originating and championing AFFNs, including the IMF (Herbst-Bayliss 2016), World Bank (E. King 2014) and OECD (Gurría 2015). Numerous state leaders have emerged in recent years as AFFN champions. For example, former President Tong of Kiribati wrote to world leaders requesting support for a global moratorium on new coalmines, ${ }^{10}$ and former US President Obama initiated numerous domestic and international policy initiatives directly targeting fossil fuels. Finally, many subnational governments have championed AFFNs, such as bans on unconventional gas "fracking" in their jurisdictions. ${ }^{11}$ The structural factors analyzed in Online Resource 1 help to explain why these kinds of actors came to advocate AFFNs. Judging by their recent activity, it seems likely that these kinds of agents will continue to originate and champion AFFNs (see also Cheon and Urpelainen 2018).

\section{The spread and effects of AFFNs}

I turn now to establishing my claims that AFFNs are likely to spread widely among the international system and have a significant causal effect on the identity-related considerations or rational calculations of states in the direction of limiting or reducing the production or consumption of fossil fuels.

The key theoretical concept used here is the feedback effect, which can be defined, for present purposes, simply as an effect that a given political intervention has on a political variable which, in turn, is a cause of a relevant future effect. The political variables could be structural phenomena like institutions, resource distributions and available technology, or agential phenomena like the identities, values, and preferences of agents. The "policy feedback effect" is a theoretical construct widely employed by political scientists to explain how policy interventions are not only the effects of (past) politics, but also the causes of (future) politics and hence (future) policy outcomes (see, e.g., Pierson 1993). A policy intervention can have "positive" feedback effects, reinforcing the direction of the original change over time and/or "negative" feedback effects, causing political counter-reactions that work against the original change (Pierson 1993). Policy feedback effects are beginning to be employed insightfully by political scientists working on the politics of climate policy (e.g. Lockwood 2013; Urpelainen

\footnotetext{
$\overline{9}$ See, e.g., Gunningham (2017a, 318-19) (on divestment); and http://www.nonewcoalmines.org.au/ (on the "no new coalmines" norm).

${ }^{10}$ President Tong's letter is available from http://www.nonewcoalmines.org.au/president_of_kiribati.

${ }^{11}$ See https://keeptapwatersafe.org/global-bans-on-fracking/.
} 
2013). But it is not only policy interventions that have feedback effects: norms also exhibit complex dynamics that can appropriately be analyzed in terms of feedback effects. The below discussion explicates the generic processes by which AFFNs are likely to have positive feedback effects.

\subsection{Pressure from within: political mobilization by domestic civil society}

I first consider how AFFNs are likely to spread and affect states via political mobilization by domestic civil society actors seeking to influence the state in which they operate.

Scholars of domestic social movements have recognized that political mobilization can affect the rational (e.g., electoral) calculations of a state's government and political parties in ways that make it more likely that the state will adopt climate policies (McAdam 2017; Nulman 2015). Bomberg defines political mobilization as "galvanizing resources and people to participate actively" in politics (Bomberg 2012, 408). She argues that, to influence climate policy successfully, mobilization requires awareness-raising, alliance-building and multi-level network-formation. Recently, increasing scholarly attention within the literature on norms has been paid to the (counter-)mobilization of groups opposed to new moral norms and the effects of such conflict on the norm's content and diffusion (see Online Resource 1, Sec. 1). Domestic anti-fossil fuel activists will undoubtedly continue to face fierce resistance from powerful opponents protecting an entrenched status quo — not least the fossil fuel industry — with respect to all elements of political mobilization. Accordingly, analysis of domestic mobilization processes must take into account these oppositional dynamics, too.

Civil society activism built around AFFNs, I argue, is likely to be more effective with respect to each of these three elements of political mobilization, and to undermining opponents' counter-mobilization, compared with similar activism focused on climate change per se. Consequently, AFFN-related activism is more likely to increase electoral incentives for governments to limit or reduce fossil fuel production or consumption.

\subsubsection{Awareness-raising and framing}

In order to raise awareness and attract wide public support for their cause, global moral norms must be compellingly "framed" by norm entrepreneurs/champions (Finnemore and Sikkink 1998; Gauri 2012). Generally, the literature on norm framing overlaps extensively with the literature on "collective action framing" by social movements (Benford and Snow 2000) and, in this context, the interdisciplinary literature on climate-related framing/communication (Corner et al. 2014; van der Linden et al. 2015; Moser 2016). Synthesizing from these literatures, three findings about the links between framing and political mobilization are pertinent. Frames are likely to be more resonant where they are:

(i) Intuitively plausible to lay audiences, in that they appeal to common sense understandings of (a) facts/reality (e.g., personal experience and simple facts, rather than requiring complex cognitive tasks or technical expertise) and (b) values/morality (e.g., values that are widely-shared and intuitive, rather than narrowly-shared and requiring complex utilitarian calculations);

(ii) Relevant to the audience's everyday concerns and priorities; and

(iii) Delivered by messengers perceived by the target audience to be credible and in an authoritative forum or context relevant to that audience. 
Motivating more engaged forms of participation in collective action (such as participation in protests and other social movement activities) is likely to additionally require frames that trigger intense emotions such as moral indignation or pride (Jasper 2011).

Based on these insights, AFFNs have the potential to be more effective at engaging the lay public than the kinds of climate change norms historically appealed to by climate activists and embedded in UN treaties (see Section 1 and Online Resource 1).

First, AFFNs are amenable to framing using clear and simple language. Fossil fuels and associated infrastructure are readily understood by lay audiences. In contrast, concepts such as greenhouse gases, " $2{ }^{\circ} \mathrm{C}$ average warming", and " $350 \mathrm{ppm}$ " are abstract, technical constructions not readily grasped by laypersons (Gauri 2012, 11). Moreover, the prohibitionary AFFNs with which I am concerned are straightforward deontological imperatives, whereas grasping climate change goals typically requires cognitively demanding forms of ethical reasoning, such as utilitarian calculation or the resolution of multiple conflicts among rights and duties (Green 2017). These features make the empirical and moral messages associated with AFFNs more intuitively plausible (e.g., "coal kills: no new coalmines!").

Second, AFFNs ameliorate a major challenge faced by climate campaigners: the harms caused by climate change are causally complex and (perceived to be) remote from their cause in time and space (van der Linden et al. 2015). The production, transport and consumption of fossil fuels, however, in addition to causing climate change, cause and are popularly associated with a range of other harms. These may include adverse local environmental, health and social impacts, corruption, repressive governance practices, human rights abuses, energy insecurity, and economic volatility. Most of these harms affect communities temporally and physically proximate to the cause and in a direct and causally obvious, often physical way. These features make the impacts of fossil fuel activities easier to understand, more intuitively morally wrong, more relevant to the everyday concerns and priorities of target audiences, more likely to trigger feelings of indignation among diverse groups, and ultimately more likely to motivate engaged forms of social movement participation, compared with the impacts of climate change.

Third, AFFNs personalize the causes of climate change, thus strengthening the intuitiveness of their moral wrongness and more readily triggering feelings of indignation, compared with a climate change frame. As Keck and Sikkink note, "problems whose causes can be assigned to deliberate (intentional) actions of identifiable individuals are amenable to advocacy network strategies [including political mobilization] in ways that problems whose causes are irredeemably structural are not" (Keck and Sikkink 1998, 27). One of the reasons that climate change is not psychologically salient is precisely that its cause is (perceived to be) structural: it is (commonly framed as) an unintentional side-effect of the everyday actions of billions of people. So understood, it lacks an identifiable causal agent intending the kind of wrongdoing that automatically violates our moral intuitions (Markowitz and Shariff 2012, 244). Anti-fossil fuel initiatives, by contrast, help to concentrate moral pressure on the largest culprits of climate change, which makes such initiatives more effective at inspiring public anger/indignation (McAdam 2017, 204). Indeed, this is a key factor motivating AFFN entrepreneurship, especially the divestment movement (Gunningham 2017b, 378). As Bill McKibben has put it, "movements require enemies" and "the fossil-fuel industry ... is Public Enemy Number One", noting that just six of the largest listed oil and gas companies alone hold reserves that together "would use up more than a quarter of the remaining two-degree budget" (McKibben 2012, citing Carbon Tracker Initiative 2011).

This concentration of moral pressure on fossil fuel companies is also an important means by which anti-fossil fuel campaigners can undermine their more powerful opponents. While 
activist groups cannot come close to matching the fossil fuel industry's financial resources, its elite political relationships or its "structural" power in our fossil fuel-dependent global economy, they typically do enjoy considerable "discursive" and "symbolic" power, meaning battles over ideas and legitimacy tend to be less one-sided (Gunningham 2017b, 382-85; Ayling 2017). Moralized anti-fossil fuel frames therefore play to activists' comparative advantage, threatening to stigmatize the fossil fuel industry in the eyes of the wider public (Ansar et al. 2013; Seidman 2015) and to sap its legitimacy - a crucial intangible resource affecting its ability to realize its objectives (Ayling 2017, 351).

To counter the mounting moral pressure and mitigate the risk of stigmatization, threatened industries tend to deploy "moral" counter-frames that attempt to justify their harmful practices, and this is exactly what the fossil fuel industry is now doing (Ayling 2017, 358, 361; Jamieson 2017; Seidman 2015, 1033). Yet the industry's moral justifications are often transparently implausible, as with the coal industry's public relations campaign that casts its objectives in moral terms of helping the world's energy poor (e.g., Sheppard 2014), and are thus easily debunked or parodied. ${ }^{12}$ But the industry has also responded to the heightened moral pressure of anti-fossil fuel activism by doubling down on its use of more naked, instrumental forms of power. For example, political corruption and heavy-handed tactics to repress activist opposition have allegedly been deployed by proponents of the Keystone XL and Dakota Access Pipelines (Federman 2013; S. King 2016; Rainforest Action Network et al. 2017, 52). Such tactics, in turn, further deplete the company/industry's legitimacy, undermine its "moral" counter-frames, and further increase the likelihood of stigmatization.

Empirical evidence suggests that the framing resonance and awareness-raising potential of AFFNs is strong. Survey evidence about energy sources in the USA and Australia, for example, supports the claim that anti-fossil fuel frames are likely to be more resonant than generic climate change frames (Anonymous 2016; Ansolabehere and Konisky 2014; Kennedy 2017; Lewis 2017), and in China, local air pollution (caused by fossil fuels) is one of the highest issues of public concern (Wike and Stokes 2016). Case studies indicate the potential for proposed fossil fuel infrastructure to generate strong local opposition, conflict among opponents and proponents/supporters, and wider media attention (Bomberg 2017; Cheon and Urpelainen 2018; Connor 2016; Connor et al. 2009, 501-3; Ordner 2017). The divestment movement, with its moralized anti-fossil fuel frame, has in a very short time, enhanced public discourse on climate change, increasing the traction of both anti-fossil fuel messages and more mainstream, liberal climate policy responses in public debate (Schifeling and Hoffman 2017; see also Ayling and Gunningham 2017; Gunningham 2017a, 317-19; Seidman 2015, 1030-34).

\subsubsection{Alliance-building and network-formation}

AFFN-related frames also have advantages over traditional climate change frames with respect to alliance-building and network-formation. The multiple negative impacts of fossil fuels at multiple scales facilitate the building of strong, diverse alliances and networks whose constituents share a common opponent.

Case studies attest to the diversity of local-scale actors that can be incited to oppose fossil fuel projects, including residents, farmers, ranchers, indigenous peoples, church groups and health professionals (Bomberg 2017; Cheon and Urpelainen 2018; Connor 2016; Connor et al. 2009; Ordner 2017). The concrete, local struggles that unite these groups, moreover, raise the

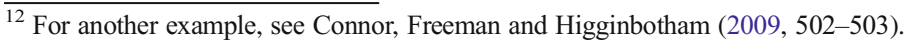


potential for "small victories" in ways that campaigns on climate change per se do not, and such victories reinforce the sense of hope and collective efficacy necessary to sustain social movement engagement over time (McAdam 2017, 205).

Anti-fossil fuel frames also facilitate alliance-building and multi-level network-formation between these local actors and larger environmental groups motivated primarily by the climate impacts of proposed projects (Bomberg 2017; Connor 2016, 239; Connor et al. 2009; Hopke 2016). The two have complementary resources that enhance the effectiveness of their combined activism: from the larger groups, the local actors can gain information, technical expertise, logistical support, access to policymakers, and access to loose networks at larger scales (national, regional, transnational and "translocal"); meanwhile, local actors bring local knowledge (e.g., of local fossil fuel impacts), denser, local-scale networks, and powerful symbolic resources (e.g., locally resonant stories, images and messengers) that global climate change campaigns often lack (Bomberg 2017; Connor 2016; Connor et al. 2009; Hopke 2016). While these interactions among diverse constituencies sometimes create tensions (Connor 2016, 239), there is plenty of evidence that they can also expand the knowledge, concerns and identities of participants; farmers become climate activists, and climate activists becomes indigenous rights advocates, for example (Connor et al. 2009, 506-9; Ordner 2016, 162). These movement-building impacts are likely to have longer-term strategic benefits, irrespective of the outcomes of specific fossil fuel projects/campaigns (Connor et al. 2009, 506-9; Ordner 2016, 162).

The concentration of moral pressure onto target companies/industries, discussed earlier, can also undermine the latter's external relationships. Specifically, it can help to isolate them from private supporters and enabling institutions (e.g., sources of finance and cultural legitimacy) who may be more sensitive than fossil fuel companies themselves to the effects of such pressure on their own reputations, legitimacy and/or profits (Devers et al. 2009; King and Pearce 2010, 255-56). AFFNs arguably have strong potential to achieve such effects, primarily through targeting institutional investors and educational, religious and cultural institutions that enable or support fossil fuels (Ayling and Gunningham 2017; Gunningham 2017b; Seidman 2015; and see, e.g., Rainforest Action Network et al. 2017).

Ultimately, effective political mobilization against fossil fuel industry targets can cause delays to or cancelations of planned projects, and can raise political and legal risks that interact with economic variables to affect the viability of projects - as campaigns against US coal-fired power stations, Canadian tar sands projects, and north American pipeline projects attest (Cheon and Urpelainen 2018; Sanzillo et al. 2014). Such mobilization also has the potential to change electoral outcomes by shifting the composition of advocacy coalitions and altering public opinion, facilitating the (full or partial) institutionalization of specific movement goals into policy and/or enabling wider climate-energy policy shifts (Cheon and Urpelainen 2018; Schifeling and Hoffman 2017). These domestic outcomes, in turn, can strengthen global AFFNs ("no new oil pipelines"; "phase out coal" etc.).

\subsection{International socialization}

The second set of processes by which AFFNs are likely to spread and affect states occurs at the international level and involves attempts by norm champions - and for simplicity I will here focus only on state norm champions - to socialize other states ("target states") to adopt an AFFN.

The analysis below makes the following assumptions, drawing on the literature on state socialization. First, it is assumed that the state is a corporate agent and that it is thus 
meaningful to conceptualize it as a distinct agent, while recognizing that its behaviour is a function of many individual persons' behaviour and interactions (Flockhart 2006). Second, following Flockhart (2006), a distinction is drawn between a state's political elite (here defined as government officials) and the wider public, represented by the civil society (as depicted in Section 3.1, above). Third, it is assumed that the tactics by which a norm champion may seek to socialize a target state (via its government officials) include modeling appropriate behaviour (i.e. leading by example) (Thies 2003, 548-49), persuasion (attempting to change another's mind using argument, without overt coercion) and social influence (eliciting pro-norm behavior through the distribution of social rewards and punishments such as praise/blame, esteem/disesteem, back-patting/opprobrium, inclusion/exclusion) (Johnston 2001, 496-506). ${ }^{13}$ Together, these assumptions allow a more detailed specification of hypotheses about the micro-processes by which norm champions' socialization tactics induce target states to adopt AFFNs.

Fourth, it is assumed that the motivations of states to adopt norms in light of socialization tactics may range from, at one extreme, a dominant "logic of appropriateness", whereby the target state accepts that the new norm constitutes appropriate behaviour for it, in light of its perceived international identity or role conception (e.g. "developed state", "liberal state") to, at the other extreme, a dominant "logic of consequences", whereby the target state adopts the new norm because it rationally calculates that the benefits of doing so outweigh the costs (March and Olsen 1996; cf. Choi 2015). In practice, a mixture of these "ideal-type" motivations is typical, and states'officials' particular mix of motivations will differ from context to context (Choi 2015). This assumption facilitates flexibility in the analysis of state motivations for adopting AFFNs, recognizing that appropriateness and consequence logics may be convergent in some cases, divergent in others (Choi 2015, 120-22). It also facilitates rational choice analysis that aggregates social benefits (and costs) to states/officials, such as enhanced international reputation or status from adopting an AFFN, with material costs (and benefits), such as the domestic net economic costs of implementing such a norm (Johnston 2001, 502-6).

\subsubsection{Targeting potential early adopters}

It is hypothesized that, in the early stages of an AFFN's international diffusion, rational norm champion states will use a combination of persuasion and modeling to try to socialize early adopters, and will focus on target states that meet the following two criteria: (i) the target state has an international identity or role conception linked to strong climate action, such that nonadoption of the AFFN would be strongly dissonant (e.g., the state identifies as a "climate leader" or, more generally, a "progressive" state); and (ii) the perceived material costs to the target state from adopting the AFFN are low (e.g., the state is not a major producer or consumer of the relevant type of fossil fuel).

This hypothesis reflects the greater effectiveness of persuasion among like-minded peers relative to social influence tactics when a norm is not yet widely adopted among states (Johnston 2001, 509-10). Social influence tactics are likely to be relatively ineffective in the early stage of a norm's diffusion because the (international) social benefits accruing to early norm adopters are likely to be relatively low (Johnston 2001, 503-6). Accordingly, rational

\footnotetext{
${ }^{13}$ This definition of socialization excludes coercion and the provision of material incentives (e.g. side-payments or sanctions). Scholars differ as to whether they include one or both of these within their definitions of socialization (compare, e.g., Flockhart 2006; Johnston 2001; Thies 2003, 548).
} 
AFFN champions will seek to persuade state peers who share a common (climate-progressive) identity and face low material costs to adopting the AFFN. Modeling appropriate behaviour also seems likely to be prevalent as an early stage tactic, as this allows for evidence of causal effectiveness to be accumulated and enhances norm champions' legitimacy, thus complementing persuasion tactics.

The launch at COP23 (November 2017) of the new Powering Past Coal Alliance illustrates the plausibility of this hypothesis. The Alliance consists of national and provincial governments committed to phasing out unabated coal-fired power generation within their jurisdiction. Led by the UK and Canada, the Alliance's founding members are mostly developed European countries, wealthier US and Canadian provinces, and small island developing states (Government of Canada 2017). Most of these jurisdictions have a pre-existing climateprogressive identity. And most have relatively few coal-fired power stations ${ }^{14}$ meaning the material costs of adopting this AFFN are low. Modeling tactics were prominent among the Alliance's founding members: a number of them had made unilateral coal phase-out commitments prior to joining the alliance (see Littlecott and Webb 2017), and the timing and fanfare associated with the launch at COP23 were clearly orchestrated to model appropriate behaviour (see Webb and Littlecott 2017). The Alliance Declaration, moreover, clearly states the intention of the founding members to use persuasion tactics to expand membership of the Alliance: it states that "We will also encourage our peers to join us in powering past coal to build a better world for our children and grandchildren", and declares the goal of having 50 members by COP24 in December 2018 (Government of Canada 2017).

\subsubsection{Positive feedback effects: rising social costs of non-adoption, norm cascades, and domestic interactions}

The diffusion of norms is not, however, simply a matter of persuading states, one-by-one; cases of successful international norm diffusion are characterized by positive feedback mechanisms. Specifically, we can expect the use of social influence tactics, and hence the identity dissonance and/or social costs (e.g., international opprobrium, reputational damage) to a nonadopting state, to grow as a function of the number of other states that have adopted the norm (Finnemore and Sikkink 1998, 902-4; Johnston 2001, 503-10). This feature of norm diffusion gives rise to "tipping" dynamics: once a "critical mass" of states adopts a norm-possibly as a result of the norm's institutionalization - a "cascade" will be triggered, whereby many other states adopt it in rapid succession (Finnemore and Sikkink 1998). It is hypothesized that AFFNs will follow this norm diffusion pattern (albeit with variation and uncertainty as to the "critical mass" from norm to norm) among states for whom norm adoption motivations are mixed and divergent (Choi 2015, 120-22) - i.e., they have either a strong climate-progressive identity but high perceived material costs of adoption (Norway is perhaps a good example in relation to AFFNs pertaining to oil) or a weak climate-progressive identity but low perceived material costs of adoption. For such states, the rising social costs of non-adoption (social benefits of adoption) as the norm spreads are likely to tip them toward adoption.

Of course, there are likely to be holdout states that resist AFFNs' diffusion. We can hypothetically expect states with powerful and/or growing fossil fuel industries, and which do not identify as progressive climate leaders, to take such a position (Saudi Arabia and Russia are perhaps good examples). For such states, rational calculation is likely to be their dominant

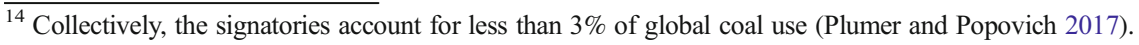


motivation and the perceived material benefits of non-adoption are likely to exceed the associated social costs. Indeed, due to the operation of global market forces, the material economic benefits of non-cooperation are likely to grow as a function of the number of other states adopting AFFNs (Collier and Venables 2015).

AFFNs will not magically dissolve the material incentives for certain countries to produce and consume fossil fuels. The crucial point is, rather, that the feedback mechanisms associated with the spread of norms will nonetheless affect theses states. Theory on norm diffusion predicts that the social costs - to reputation, status etc. - on holdouts of failing to adopt a norm will become highly intense when only a few of them remain (Collier and Venables 2015, 5034; Jacquet 2015, 71-74). Consequently, holdout states must spend considerable political/ diplomatic capital to mitigate international opprobrium (see, e.g., Klotz 2002 on apartheid South Africa and pre-abolition USA). Over time, these costs can become unsustainable, leading to a change of position.

Additionally, these international pressures can have positive feedback effects within the civil society of holdout states that can also lead to a shift in position over time. These can be theorized as interactions between the international socialization processes discussed here and the domestic political mobilization processes discussed in Section 3.1. First, widely adopted global norms can provide a focal point around which civil society actors in holdout states can mobilize and which legitimizes their claims (Dai 2010). Second, widely adopted norms provide a benchmark against which a holdout state can be held accountable by third parties, including domestic civil society actors, even though that state has not adopted the norm. This further increases the moral and political pressure on states to adopt the norm (Dai 2010; Keck and Sikkink 1998, 24). As AFFNs become more widespread, opportunities will arise to test these hypotheses. Tracking the spread and effects of the Powering Past Coal Alliance (discussed above) would, for example, be a fruitful topic of future research.

\section{Conclusion}

This article has sought to draw attention to, and explain the logic of, an emerging and promising phenomenon in global climate governance. It has argued, first, that international structural conditions are more conducive than at any previous time to the spread of AFFNs (see Online Resource 1). In particular, AFFNs cohere with, and take forward, the logics of "political mobilization" and "peer pressure" at the heart of the Paris Agreement. Second, it argued that AFFNs are likely to continue to be originated and advocated by various kinds of norm entrepreneurs and champions. Third and most significantly, it identified two channelsdomestic political mobilization by civil society actors, and international socialization by states (and non-state actors) - by which AFFNs are most likely to spread widely throughout the international system, and to affect the identity-related considerations or rational calculations of states in the direction of limiting or reducing fossil fuel production or consumption.

AFFNs provide fertile ground for future multidisciplinary research in numerous directions. First, detailed case studies of specific anti-fossil fuel initiatives, and resulting AFFNs, would provide valuable tests of and refinements to the arguments developed here, while also contributing to the development of the wider literature on global moral norms. Second, comparative studies could help to identify systematic variation in the conditions affecting the strength of the causal mechanisms identified in Section 3. For example, domestic civil society mobilization is likely to be less effective in countries where the political space for such 
mobilization is narrow (Falkner 2016, 1123; Flockhart 2006, 105-8). Third, more research is needed on the complementarities and/or tensions between AFFNs (the "negative" goals) and other desirable climate-related norms, frames and initiatives, such as 100\% renewable energy / green transformation (the "positive" goals) and "just transition" (the hinge between the negative and positive goals) (Green 2017; see Online Resource 1, sec. 3).

It is hoped that this article will contribute to a greater understanding among climate governance scholars of this promising new mode of climate governance, will tempt international relations scholars of moral norms to engage more closely with climate and energy issues, and will assist AFFN champions to maximize the effects of their initiatives to mobilize civil society and socialize states.

Acknowledgements I am grateful to Christian Downie, Robert Falkner, Michael Lazarus, Stephen Minas, Elizabeth Morrow, Harro van Asselt and three anonymous reviewers for helpful comments on drafts of the paper. Lindsey Allen, Tzeporah Berman, Richard Denniss and Tom Swann provided useful suggestions regarding antifossil fuel initiatives. Daniel Wiseman provided helpful research assistance toward the first draft, which was presented at the conference on Fossil Fuel Supply and Climate Policy at Oxford in September 2016. I gratefully acknowledge the support of The Australia Institute, which provided a small grant for that research assistance.

Open Access This article is distributed under the terms of the Creative Commons Attribution 4.0 International License (http:/creativecommons.org/licenses/by/4.0/), which permits unrestricted use, distribution, and reproduction in any medium, provided you give appropriate credit to the original author(s) and the source, provide a link to the Creative Commons license, and indicate if changes were made.

\section{References}

Andonova LB, Betsill MM, Bulkeley H (2009) Transnational climate governance. Glob Environ Polit 9(2):52-73

Anonymous (2016) Factsheet: Australians strongly back renewable energy and a plan to manage the phase-out of coal stations. The Climate Institute. http://www.climateinstitute.org.au/verve/_resources/CoN_2016_ Energy_Factsheet_26092016.pdf

Ansar A, Caldecott B, Tilbury J (2013) Stranded assets and the fossil fuel divestment campaign: what does divestment mean for the valuation of fossil fuel assets? Smith School for Enterprise \& Environment, Oxford

Ansolabehere S, Konisky DM (2014) Cheap and clean: how Americans think about energy in the age of global warming. MIT Press, Cambridge, MA

Ayling J (2017) A contest for legitimacy: the divestment movement and the fossil fuel industry. Law \& Policy 39(4):349-371

Ayling J, Gunningham N (2017) Non-state governance and climate policy: the fossil fuel divestment movement. Clim Pol 17(2):131-149

Bäckstrand K, Lövbrand E (2015) Research handbook on climate governance. Edward Elgar

Benford RD, Snow DA (2000) Framing processes and social movements: an overview and assessment. Annu Rev Sociol 26:611-639

Blondeel M, Van de Graaf T (2018) Toward a global coal mining moratorium? A comparative analysis of coal mining policies in the US, China, India, and Australia. Climatic Change. https://doi.org/10.1007/s10584017-2135-5

Bomberg E (2012) Mind the (mobilization) gap: comparing climate activism in the United States and European Union. Rev Policy Res 29(3):408-430

Bomberg E (2017) Shale we drill? Discourse dynamics in UK fracking debates. J Environ Policy Plan 19(1):72-88 Caney S (2014) Two kinds of climate justice: avoiding harm and sharing burdens. J Polit Philos 22(2):125-149

Carbon Tracker Initiative (2011) Unburnable Carbon - Are the World's Financial Markets Carrying a Carbon Bubble? http://www.carbontracker.org/wp-content/uploads/downloads/2011/07/Unburnable-Carbon-Fullrev2.pdf

Cheon A, Urpelainen J (2018). Activism and the Fossil Fuel Industry. Routledge

Choi J (2015) Rationality, norms and identity in international relations. Int Polit 52(1):110-127

Collier P, Venables AJ (2015) Closing coal: economic and moral incentives. Oxf Rev Econ Policy 30(3):492-512 
Connor L (2016) Energy futures, state planning policies and coal mine contests in rural New South Wales. Energy Policy 99:233-241

Connor L, Freeman S, Higginbotham N (2009) Not just a coalmine: shifting grounds of community opposition to coal Mining in Southeastern Australia. Ethnos 74(4):490-513

Corner A, Markowitz E, Pidgeon N (2014) Public engagement with climate change: the role of human values. WIREs Clim Change 5(3):411-422

Dai X (2010) Global regime and national change. Clim Pol 10(6):622-637

Devers CE, Dewett T, Mishina Y, Belsito CA (2009) A general theory of organizational stigma. Organ Sci 20(1): 154-171

Drahos P, Downie C (2016) Regulatory unilateralism: arguments for going it alone on climate change. Global Pol $8(1): 32-40$

Falkner R (2016) The Paris agreement and the new logic of international climate politics. Int Aff 92(5): $1107-1125$

Federman A (2013) The fossil fuel industry's secret war on environmental activists. Salon.com. http://www. salon.com/2013/08/08/the fossil fuel industrys secret war on environmental activists partner/

Finnemore M, Sikkink K (1998) International norm dynamics and political change. Int Organ 52(4):887-917

Fitzsimmons S (2009) A rational-constructivist explanation for the evolution and decline of the norm against mercenarism. J Mil Strateg Stud 11(4):1-35.

Flockhart T (2006) 'Complex socialization': a framework for the study of state socialization. Eur J Int Relat 12(1):89-118

Gauri V (2012) MDGs That Nudge: The Millennium Development Goals, Popular Mobilization, and the Post2015 Development Framework. Policy Research Working Paper No. 6282, World Bank, Washington, DC

Government of Canada (2017) Powering Past Coal Alliance Declaration. https://www.canada. $\mathrm{ca} / \mathrm{en} / \mathrm{services} / \mathrm{environment/weather/climatechange/canada-international-action/coal-phase-out/alliance-}$ declaration.html

Green F (2017) The Normative Foundations of Climate Legislation. In: Averchenkova A, Fankhauser S, Nachmany M (eds) Trends in climate change legislation. Edward Elgar, London, pp 85-107

Gunningham N (2017a) Review essay: divestment, nonstate governance, and climate change. Law Policy 39(4): 309-324

Gunningham N (2017b) Building norms from the grassroots up: divestment, expressive politics, and climate change. Law Policy 39(4):372-392

Gurría A (2015) Overcoming climate change and unleashing a dynamic, zero-carbon economy. The OECD Obs 304:2-3

Herbst-Bayliss S (2016) IMF's Lagarde eyes subsidies, simple things to tackle climate change. Reuters. http:/www.reuters.com/article/us-imf-lagarde-idUSKCN0W62OI

Hopke JE (2016) Translocal anti-fracking activism: an exploration of network structure and tie content. Environ Commun 10(3):380-394

Jacquet J (2015) Is shame necessary? New uses for an old tool. Penguin Books, London

Jamieson D (2017) Slavery, carbon, and moral progress. Ethical Theory Moral Pract 20(1):169-183

Jasper JM (2011) Emotions and social movements: twenty years of theory and research. Annu Rev Sociol 37(1): 285-303

Johnston AI (2001) Treating international institutions as social environments. Int Stud Q 45:487-515

Keck ME, Sikkink K (1998) Activists beyond borders: advocacy networks in international politics. Cornell University Press, Ithaca, NY

Kennedy B (2017) Two-thirds of Americans give priority to developing alternative energy over fossil fuels. Pew Research Centre. http://www.pewresearch.org/fact-tank/2017/01/23/two-thirds-of-americans-give-priorityto-developing-alternative-energy-over-fossil-fuels/

King E (2014) World Bank chief backs fossil fuel divestment drive. Climate Home. http://www. climatechangenews.com/2014/01/27/world-bank-chief-backs-fossil-fuel-divestment-drive/

King S (2016) Crossing the fossil fuel industry could now get you locked up - for decades. ACLU. https://www. aclu.org/blog/speak-freely/crossing-fossil-fuel-industry-could-now-get-you-locked-decades

King BG, Pearce NA (2010) The contentiousness of markets: politics, social movements, and institutional change in markets. Annu Rev Sociol 36:249-267

Klotz A (2002) Transnational activism and global transformations: the anti-apartheid and abolitionist experiences. Eur J Int Relat 8(1):49-76

Lewis P (2017) The Canberra Coal Club ignores what most people know: the future will be clean and smart. The Guardian (Australia). https://www.theguardian.com/commentisfree/2017/feb/21/the-canberra-coal-clubignores-what-most-people-know-the-future-will-be-clean-and-smart?CMP=share_btn_fb

Littlecott C, Webb M (2017) Accelerating Coal Phase Out: The OECD Context. E3G Briefing Paper. https://www.e3g.org/docs/Accelerating_Coal_Phase_Out_-_the_OECD_context_18_09_17.pdf 
Lockwood M (2013) The political sustainability of climate policy: the case of the UK climate change act. Glob Environ Chang 23(5):1339-1348

March JG, Olsen JP (1996) Institutional perspectives on political institutions. Governance 9(3):247-264

Markowitz EM, Shariff AF (2012) Climate change and moral judgement. Nat Clim Chang 2(4):243-247

McAdam D (2017) Social movement theory and the prospects for climate change activism in the United States. Annu Rev Polit Sci 20:189-208

McKibben B (2012) Global Warming's Terrifying New Math. Rolling Stone. http://www.rollingstone. com/politics/news/global-warmings-terrifying-new-math-20120719

Moser SC (2016) Reflections on climate change communication research and practice in the second decade of the 21st century: what more is there to say? WIREs Climate Change 7:345-369

Nulman E (2015) Climate change and social movements. Palgrave Macmillan, New York

Ordner JP (2017) Community action and climate change. Nat Clim Chang 7:161-163

Osborne S (2017) Ireland votes in favour of law to become world's first country to fully divest from fossil fuels. Independent, 27 January. http://www.independent.co.uk/news/world/europe/ireland-votes-divest-fossilfuels-climate-change-world-first-country-parliament-renewable-energy-a 7549121.html

Pierson P (1993) When effect becomes cause: policy feedback and policy change. World Politics 45(4):595-628

Plumer B, Popovich N (2017) 19 Countries Vowed to Phase Out Coal. But They Don't Use Much Coal. New York Times, 16 November. https://www.nytimes.com/interactive/2017/11/16/climate/alliance-phase-outcoal.html

Pope Francis (2015) Encyclical letter Laudato si' of the holy father Francis on care for our common home. Vatican. http://w2.vatican.va/content/dam/francesco/pdf/encyclicals/documents/papa-francesco_20150524_ enciclica-laudato-si_en.pdf

Rainforest Action Network, BankTrack, Sierra Club, and Oil Change International (2017) Banking on Climate Change: Fossil Fuel Finance Report Card 2017

Raymond L et al (2014) Making change: norm-based strategies for institutional change to address intractable problems. Polit Res Q 67(1):197-211

Sanzillo T et al (2014) Material risks: how public accountability is slowing tar sands development. Oil Change International, Washington, DC

Schifeling T, Hoffman A (2017) Bill McKibben's influence on U.S. climate change discourse: shifting field-level debates through radical flank effects. Organizations \& Environment. https://doi.org/10.1177 $/ 1086026617744278$

Seidman G (2015) Divestment dynamics: mobilizing, shaming, and changing the rules. Soc Res 82(4): 1015-1037

Sheppard K (2014) World's Biggest Coal Company, World's Biggest PR Firm Pair Up to Promote Coal for Poor People. The Huffington Post. http:/www.huffingtonpost.com/2014/03/27/peabody-burson-marstellar-coal_ n_5044962.html?1395959081

Stavins R et al. (2014) International cooperation: Agreements \& Instruments. In: Edenhofer O et al (eds), Climate change 2014: mitigation of climate change. Contribution of Working Group III to the Fifth Assessment Report of the Intergovernmental Panel on Climate Change, Cambridge University Press, Cambridge, 1001-1082

Thies CG (2003) Sense and sensibility in the study of state socialisation: a reply to Kai Alderson. Rev Int Stud 29(4):543-550

Urpelainen J (2013) A model of dynamic climate governance: dream big, win small. Int Environ Agreements Polit Law Econ 13(2):107-125

van der Linden S, Maibach E, Leiserowitz A (2015) Improving public engagement with climate change: five "best practice" insights from psychological science. Perspect Psychol Sci 10(6):758-763

Webb M, Littlecott C (2017) Powering past coal at COP23. E3G (Blog Post), 16 November. https://www.e3g. org/library/powering-past-coal-at-cop23

Wike R, Stokes B (2016) Chinese Public Sees More Powerful Role in World, Names U.S. as Top Threat. Pew Research Center. http://www.pewglobal.org/2016/10/05/chinese-public-sees-more-powerful-role-in-worldnames-u-s-as-top-threat/ 